\title{
PEMAHAMAN HADIS RU 'YATAL-HILAL MENURUT ULAMA SYATARIAH ULAKAN PADANG PARIAMAN
}

\author{
Nandi Pinto \\ UIN Imam Bonjol Padang \\ nandipintoamrizal@gmail.com
}

\begin{abstract}
Abstrak. Pemahaman Hadis Ru'yatal-Hilal Menurut Ulama Syataraiah Ulakan Padang Pariaman The Problem of hisab and ru'yat on its development are not regardless of development Islamic thingking history who much be embellishment of ideology, mazhab or firqah, who present differentiation on opinion who related Islamic law framework especially in Indonesia. The result of understanding different about argumentation normative hisab-ru'yat were think out a differntiation and understanding on the Islamic member of a religious community. This thesis is field research, who has special understanding on construe of Hadis ru'yat al-hilal of Tarekat Syatariah. Interpretation this Hadith of Tarekat Syatariah have different understanding to understand the context of Hadis. Now focus of this research is to know understanding and implementation of Hadith ru'yat al-hilal according to Syatariah scholar Ulakan Padang Pariaman. The result of this research are, First, understanding of hadis ru'yat alhilal according to Syatariah scolar Ulakan Padang Pariaman is both collaboration of that hadis, because of the first hadis be explanation of the second hadis that are when the moon can't be seen with the naked eyes because closed of fog or cloud, than word of presuppositioning (faqdurulah) on the first hadis be exclamation of passages of Koran by supplying additional information by Syatariah scholar be completed Sya'ban moon to be 30 days. Second, understanding implementation of Hadis ru'yat al-hilal is with together see new moon (al-hilal) at place who be certained of scolar (Tuangku) from the last time , they are Ulakan beach Padang Pariaman and Koto Tuo Agam. They are see new moon naked eye, although use the modern tools to see it the last judgmen according to them how to see it with naked eye, if it can't be seen so, the new moon was not visible, although with modern tools to see it, and that not have influenced on determination al-hilal was seem or not. Their jedgment is still on argument if the new moon can't see with naked eyes, so, al-hilal be evidented not visible and Sya'ban moon be completed to 30 days.
\end{abstract}

Keywords : Hadith, Ru'yat, Understanding, Syatarialism

Abstrak. Pemahaman Hadis Ru'yatal-Hilal Menurut Ulama Syataraiah
Ulakan Padang Pariaman Problematika hisab dan ru'yat dalam
perkembangannya tidak terlepas dari sejarah perkembangan pemikiran Islam
yang banyak dihiasi oleh aliran, mazhab atau firqah, yang pada gilirannya
menampilkan banyaknya perbedaan pendapat dalam berbagai pandangan terkait
penerapan kerangka hukum Islam khususnya Indonesia. Muara perbedaan
pemahaman terhadap dalil normatif hisab-ru'yat, yang kemudian melahirkan
perbedaan dan pemahaman dikalangan umat Islam. Salah satunya adalah Tarekat
Syatariah yang mempunyai pemahaman tersendiri dalam menafsirkan hadis
tentang ru'yat dan hisab ini. Dari penafsiran hadis ini Tarekat Syatariah 
mempunyai beberapa perbedaan pemahaman dalam memahami kontek hadis. Adapun fokus dari penelitian ini adalah untuk mengetahui pemahaman dan implementasi hadis menurut ulama Syatariah Ulakan Padang Pariaman. Hasil dari penelitian ini adalah, Pertama, pemahaman hadis ru'yat al-hilal menurut ulama Syatariah Ulakan Padang Pariaman adalah mengkolaborasikan kedua hadis tersebut, karena hadis pertama menjadi penjelas bagi hadis yang kedua yaitu ketika bulan tidak bisa dilihat dengan mata telanjang karena tertutup kabut atau awan, maka kata perkirakanlah (faqdurulah) dalam hadis yang pertama ditafsirkan oleh ulama Syatariah menjadi disempurnakannya bulan Sya'ban menjadi 30 hari. Kedua, implementasi dari pemahaman hadis ru'yat al-hilal ini adalah dengan bersama-sama melihat bulan baru (al-hilal) di tempat yang telah ditetapkan dari dahulu yaitu pantai Ulakan Padang Pariaman dan Koto Tuo Agam dengan mata telanjang. Meskipun menggunakan alat-alat modern keputusan akhir menurut mereka adalah dengan mata telanjang, walaupun dengan bantuan ala-alat modern sudah terlihat, dan dengan mata telanjang belum terlihat, maka al-hilal dinyatakan tidak nampak dan Sya'ban di sempurnakan menjadi 30 hari.

Kata Kunci : Hadis, Ru'yat, Pemahaman, Syatariah

\section{PENDAHULUAN}

Dewasa ini perbedaan penentuan hari-hari Islam khususnya Ramadhan, Idul Fitri dan Idul Adha terdapat banyak hal yang membingungkan dikalangan masyarakat ${ }^{1}$. Salah satu permasalahannya adalah pendefenisian al-hilal yang merupakan patokan utama untuk memulai awal blan kamariah yang sangat penting bagi kaum muslimin, sebab banyak ibadah penting Islam identik dengan perhitungn bulan kamariah ${ }^{2}$.

Hal itu dijelaskan oleh Allah SWT dalam al-Qur'an al-Karim

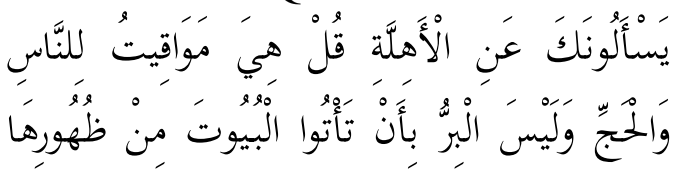

${ }^{1}$ Ahmad Izzuddin, Ilmu Falak Praktis (Metode Hisab-Rukyah Praktis Dan Solusi Permasalahannya), Semarang: Komala Grafika, 2006,p. 123-124.

${ }^{2}$ Badan Hisab dan Rukyat Departemen Agama, Almanak Hisab Rukyat, Jakarta: Proyek Pembinaan Badan Peradilan Agama Islam, 1981, p. 98.

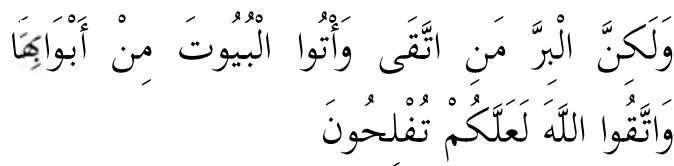

"Mereka bertanya kepadamu tentang bulan sabit (hilal). Katakanlah "Bulan sabit itu adalah tanda-tanda waktu bagi manusia dan (bagi ibadah) haji”. (QS. Al-Baqarah (2) : 189)

Ayat yang ketiga ini Allah SWT menyatakan bahwa siapa yang menyaksikan masuknya bulan Ramadlan wajib berpuasa :

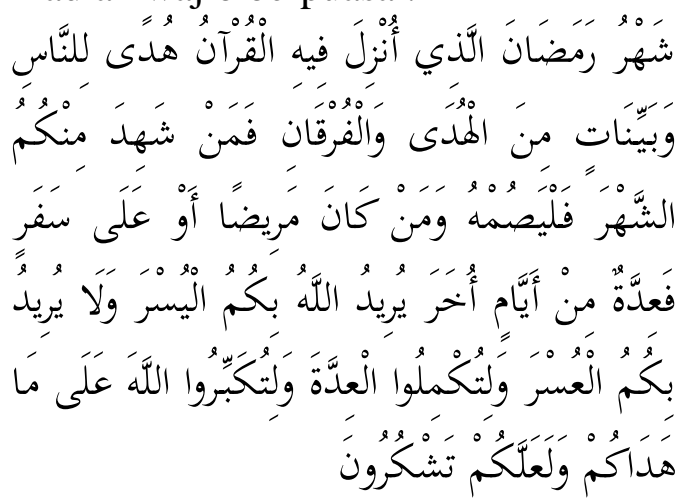

"(Beberapa hari yang ditentukan itu ialah) bulan Ramadlan, bulan yang di dalamnya diturunkan (permulaan) alQur"an sebagai petunjuk bagi manusia dan penjelasan-penjelasan mengenai 
pentunjuk itu dan pembeda (antara yang hak dan yang bathil). Karena itu, barang siapa di antara kamu menyaksikan (masuknya) bulan (Ramadlan) maka hendaklah ia berpuasa” (QS. Al-Baqarah (2) : 185)

Adapun Cara untuk mengamati hilal di lapangan dalam penentuan awal bulan kamariah adalah dengan rukyat al-hilal. Rukyat al-hilal merupakan suatu kewajiban pengamalan perintah Allah untuk memiikirkan ciptaan-Nya agar lebih mengetahui kemahabesaranNya sehingga memperkuat iman. Posisi rukyat al-hilal selain sebagai ajang pengamalan hadist nabi tentang perintah rukyat, rukyat al-hilal juga menjadi salah satu syarat dan rukun yang harus dipenuhi dalam rangka penentuan awal bulan kamariah dalam sidang istbat RI.

Rukyat al-hilal adalah usaha melihat atau mengamati al-hilal di tempat terbuka dengan mata telanjang atau peralatan pada saat matahari terbenam menjelang bulan baru kamariah pada setiap tanggal 29 bulan kamariah dengan acuan perhitungan atau hisab data astronomi pada hari yang ditentukan ${ }^{3}$. Secara harfiaah hisab berarti perhitungan. Menurut istilah Islam hisab adalah perhitungan secara matematis dan astronomis untuk menentukan posisi bulan dalam menentukan dimulainya awal bulan dalam kalender Hijriyah ${ }^{4}$. Kedua metode hisab dan rukyat al-hilal ini adalah bentuk pemahaman hadis nabi yang berkaitan dengan penentuan hari pertama bulan kamariah, seperti hadis

\footnotetext{
3 Muhyiddin Khazin, Kamus Ilmu Falak, Jogjakarta:Buana Pustaka, 2005, p. 30.

$4 \mathrm{~T}$. Jamaluddin. Pengertian dan Perbandingan Mazhab tentang Hisab Ru'yat dan Matla', Padang : Makalah Munar Tarjih Muhammadiyah ke-26.
}

yang diriwayatkan oleh Imam Muslim dan Abu Hurairah.

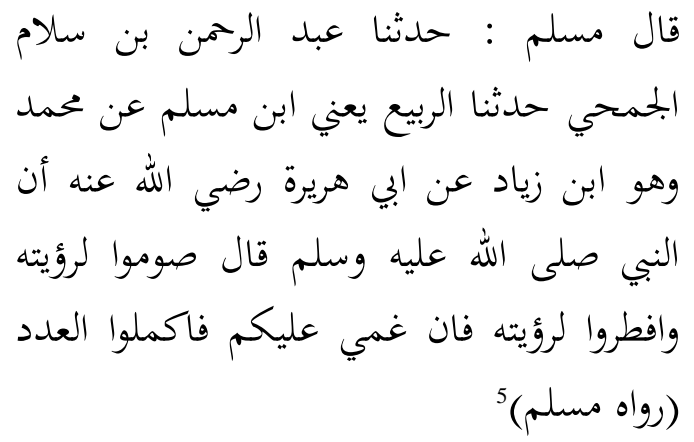

Diriwayatkan dari Abdurrahman ibn Salam al-Jumahi, dari al- Rabi' (ibn Muslim), dari Muhammad (yaitu Ibn Ziyad), dari Abu Hurairah r.a. sesungguhnya Rasulullah saw bersabda : Berpuasalah kamu karena melihat tanggal (hilal) dan berbukalah kamu karena melihat tanggal (hilal). Apabila pandanganmu terhalang oleh awan, maka sempurnakanlah bilangannya. (HR. Muslim)

Dalam redaksi lain, hadist yang diriwayatkan oleh Muslim dari Ibn Umar RA:

قال مسلم : عن ابن عمر رضي الله عنهما قال

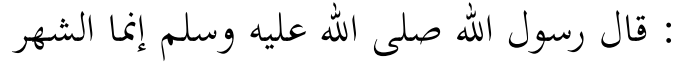
تسع وعشرون فلا تصوموا حتى تروه ولا تفطروا حتى تروه فان غم عليكم فاقدرواله (رواه (مسلم)

"Diriwayatkan dari Ibnu Umar ra. Berkata Rasulullah saw bersabda satu bulan hanya 29 hari, maka jangan kamu berpuasa sebelum melihat bulan, dan jangan berbuka sebelum melihatnya dan jika tertutup awal maka perkirakanlah. (HR. Muslim).

5 Al-Naisaburiy, Imam Abi al-Husaini Muslim ibn al-Hajjaj ibn Muslim al-Qurairiu, al-shahih al-Muslim, Beirut : Dar al-Fikri, tt, p. 481 .

${ }^{6}$ Ibid, p. 122. 
Dalam hal-hal penting berkaitan dengan agama, Nabi SAW biasanya membentuk ekspidisi guna mengurus /menjalankan sesuatu, penentuan 1 Ramadlan, Idul Fitri, dan Idul Adha adalah amat penting, karena menyangkut ibadah, tetapi tidak ada riwayat bahwa khulafaur-rasyidin $\mathrm{Abu}$ Bakar, Umar, Utsman dan Ali bin Abi Thalib pada masa pemerintahannya menindak lanjuti perintah nabi tersebut. Juga tidak ada riwayat bahwa para sahabat berbondong-bondong mengintai al-hilal, Padahal para sahabat adalah manusia yang paling antusias dan gemar menjaga dan melaksanakan perintah Rasulullah baik berupa perkataan, perbuatan maupun ketetapan beliau.

Dengan demikian hal ini menunjuk-kan bahwa perintah nabi tersebut difahami oleh para sahabat hanya berfungsi irsyad (petunjuk), sekaligus mengindikasikan bahwa menentukan pergantian bulan tersebut diserahkan kepada manusia dan kebiasaankebiasaan mereka bukan tugas kerasulan. Puasanya memang ta'abbudi tetapi penetuan tanggal 1 Ramadlan dan tanggal 1 Syawal adalah ta'aqquli.

Telah dijelaskan bahwa kebenaran agama berbeda dengan kebenaran ilmu pengetahuan. Kebanaran agama bersifat mutlak sedangkan kebenaran ilmu pengetahuan adalah bersifat nisbi, sehingga kebenaran ilmu pengetahuan terus berproses. Jika kita beranggapan bahwa menentukan tanggal 1 Ramadlan adalah bagian dari kebenaran agama yang tidak perlu berproses, maka hal tersebut akan bertentangan dengan fakta ilmu pengetahuan. Mencari tahu kapan terjadinya pergantian bulan kamariyah adalah mencari kebenaran ilmiyah, yang diperlukan adalah kesepakatan atas dasar alasan-alasan ilmiyah.

Regularitas pergerakan bendabenda langit yang dituangkan dalam bentuk yang mudah dipahami, baik yang berupa prediksi (ephemeris) atau hasil dari perhitungan, dan dari observasi lapangan dalam melakukan pengamatan bulan baru (hilal) merupakan suatu pengembangan ilmu pengetauan dalam penentuan awal bulan kamariyah, 1 Ramadhan, Idul Fitri, dan Idul Adha serta merupakan cara untuk memudahkan manusia dalam membaca pola sesuatu fenomena termasuk dalam observasi al-hilal. Tingkat keberhasilan rukyat al-hilal (pengamatan bulan baru) sangat bergantung kepada kondisi langit dan pemandangan di arah cakrawala bumi (ufuk) ${ }^{7}$.

Selain data hisab yang menunjukkan adanya kemungkinan hilal terlihat, terdapat hal lain yang perlu diperhatikan dalam rukyat al-hilal, seperti; udara kotor, awan atau kabut dan cahaya yang dapat mengganggu pandangan ke arah ufuk sehingga membuat proses pengamatan sulit untuk dilakukan ${ }^{8}$. Oleh karena itu setidaknya sebelum diadakan observasi hilal harus dilakukan langkah-langkah untuk memenuhi dan mengetahui faktor-faktor yang mempengaruhi keberhasilan dalam rukyat al-hilal.

Akan tetapi berbeda halnya dengan Jamaah Tarekat Syattariyah di daerah Ulakan Kabupaten $\mathrm{Pa}$ dangpariaman, Sumatra Barat. Jamaah Tarekat ini masih mengguna metode klasik untuk menentukan bulan baru

\footnotetext{
${ }^{7}$ Muhyiddin Khazin, op.cit, p. 85.

8 Direktorat Jenderal Bimbingan Masyarakat Islam Direktorat Urusan Agama Islam dan Pembinaan Syari'ah, Pedoman Teknik Rukyat, Jakarta : tp, 2009, p.26.
} 
dengan mata telanjang pada tanggal 29 Sya'ban. Pada dasarnya mereka menggunakan sistem Hisab yang dinamakan dengan Hisab 'urfi karena kegiatan perhitungannya berlandasakan kepada kaidah yang bersifat tradisional/tetap, yaitu dibuatnya anggaran-anggaran dalam penentuan perhitungan masuk awal bulan itu dengan anggaran yang didasarkan kepada peredaran bulan'.

Sebagaimana yang dikatakan oleh Tuangku Ali Imran yang merupakan seorang Qadhi (Imam) Tarekat Syattariyah Ulakan Pariaman,

"Tradisi melihat bulan ini dalam menentukan awal Ramadhan, memakai hitungan bilangan takwim qamsyiah, yakni hitungan berdasarkan tahunan. Kegiatan itu dilakukan dengan mata telanjang sesuai tradisi turuntemurun. Dan sesuai dengan hadis yang disampaikan oleh baginda Nabi kita Muhammad saw. Sebelum melakukan ritual melihat bulan nantinya., para jamaah Syattariyah melakukan dzikir terlebih dahulu di Surau Syekh Burhanuddin. Selanjutnya rombongan pergi menuju tepi pantai Ulakan untuk melihat bulan sebagai pedoman dalam menentukan kapan mereka mulai berpuasa."

Menurut pemaparan Tuangku Ali Imran di atas, mengidentifikasi bahwa jamaah syattariyah mengutamakan melihat hilal dengan mata telanjang dari pada menggunakan alat bantu teknologi modern, walaupun menggunakan alat bantu modern hasil akhirnya tetap dengan mata telanjang, ketika dengan alat bantu dapat dilihat dan dengan mata telanjang ternyata tidak terlihat, maka dicukupkan

\footnotetext{
${ }^{9}$ Almanak Hisab Ru'yat, Ditbinbapera Islam Depag, hal. 43
}

bilangan Sya'ban menjadi 30 hari, dan keesokannya mereka berpuasa.

Hal itu dikarenakan mereka mengaku berdalil dengan hadis Nabi saw dan takut akan melencengkan ajaran yang dibawa oleh Nabi saw, dan tetap mempertahankan hal itu sampai hari ini. Disisi lain jamaah syattariyah juga masih menjunjung tinggi perkataan pendahulu mereka dengan cara melakukan hal itu secara turuntemurun.

Adapun dasar dari penelitian ini adalah pemahaman hadist rukyat alhilal dalam perspektif syattariah dan bentuk pengaplikasian pemahaman hadist tersebut kedalam penentuan awal bulan kamariyah. Hal itu disebabkan karena banyaknya masyarakat yang menganggap bahwa aliran syattariyah sudah tidak sejalan lagi dengan alQur'an dan hadist, mereka berbeda dengan masyarakat umum kebanyakan dalam menentukan awal Ramadhan, Idul Fitri dan Idul Adha.

\section{PEMBAHASAN}

Pemahaman dari hadis ru'yat al-hilal menurut ulama Syatariah adalah adanya penyatuan atau pengkolaborasian antara kedua hadis diatas, karena pada dasarnya tidak ada hadis nabi yang bertentangan, sehingga tidak mungkin kedua hadis diatas saling berseberangan. Akan tetapi adanya peleburan makna kata hadis yang kedua yakni kata فاقدرواله (maka hisablah), jadi maksud dari hadis itu adalah pertama, perkataan qadara yang menjadi asal dari perkataan faqduru tidak pernah berarti hisablah. Dalam kitab-kitab logat tidak pernah ada qadar yang berarti hasaba. Lihat kitabkitab logat sesungguhnya Munajid pagina 644 sampai 655, Kamus al- 
Mu'tamad pagina 647, Kamus Inarah wal Tahzib keluaran Balai Pustaka pagina 703 sampai 704, Kamus alMuhith pagina 14 juz II. Kedua, dalam hadis itu perkataan "faqduru" disambungkan dengan "tsalatsina yauman" yang berarti 30 hari. Kalau diartikan perkataan "faqduru" dengan hisablah, tentu tidak cocok dengan perkataan 30 hari ("tsalatsina yauman") karena hisab itu kadangkadang 30 hari dan kadang-kadang 29 hari. Kalau ada hadis "faqduru" yang tidak disambung dengan "tsalatsina yauman" maka ia harus disambungkan dengan kalimat "tsalatsi" dalam mengartikannya, karena hadis-hadis jelas menjelaskan antara satu dengan yang lain. Ketiga, hadis "faqduru" itu didahului seluruhnya dengan kalau bulan tertutup ("fain gumma"), jadi harus berarti (menurut pendapat yang keliru ini), bahwa kalau bulan tertutup barulah dihisab. Inipun berlainan dengan pekerjaan tukang hisab sekarang, yang menghisab bulan tanpa memperdulikan tertutup atau tidak. Adakah ahli hisab menghisab bulan sesudah melihat bulan terlebih dahulu dan setelah ternyata bulan tertutup? Jawabannya : tidak. Keempat, adanya penggunaan alat modern dalam melihat bulan ketika tertutup kabut maka kami tidak melarangnya, akan tetapi kami tetap dengan keyakinan, kalau bulan tidak terlihat dengan mata telanjang maka kami genapkan Sya'ban menjadi tiga puluh hari. Kelima, agama dan hukum Agama itu adalah dari Tuhan, Nabi hanya menyampaikan syari'at. Kalau Tuhan yang punya Syari' at ingin supaya orang masuk puasa dengan hisab, tentu diajarkan-Nya kepada seluruh orang ilmu hisab itu, karena Tuhan mengetahui segala-galanya. Tetapi tuhan tidak menghendaki agar masuk puasa dengan hisab, karena itu tidak diajarkan-Nya hisab itu, ketika itu orang hanya disuruh melihat hilal dengan mata untuk masuk dan keluar puasa. Keenam, kita akui bahwa ahliahli hisab ilmu falak itu orang-orang yang ahli dan pintar menghisab, orangorang yang mengetahui jalan-nya matahari, dan jalannya bulan. Pendeknya katakanlah pintar segalagalanya. Tetapi, Tuhan tidak mensyari'atkan masuk puasa dengan hasil kepintaran orang ahli hisab itu. Yang di syari'atkan-Nya hanyalah ru'yat dengan mata, kalau dasar pikiran ini dituruti niscaya agama akan berantakan ${ }^{10}$.

Tradisi melihat bulan bagi pengikut paham Syattariyah adalah salah satu ajaran agama yang tidak boleh diragukan kebenarannya. Keyakinan tersebut masih bertahan sampai sekarang. Pada hari Jumat terakhir bulan Sya'ban, di setiap masjid yang berada di bawah pengaruh paham Syattariyah selalu disampaikan pengumuman tentang tanggal pelaksanaan kegiatan melihat bulan.

Pengumuman disampaikan oleh salah seorang imam-khatib sebelum adzan pertama dikumandangkan. Isinya antara lain tentang pelaksanaan kegiatan melihat bulan pada tanggal 29 Sya'ban menurut perhitungan taqwim. Jika hilal kelihatan, maka hari berikutnya ditetapkan sebagai tanggal 01 Ramadhan. Sebaliknya jika hilal tidak kelihatan, maka hari berikutnya

${ }^{10}$ Wawancara langsung dengan Tuangli Ali Imaran, bertempat di Pesantren Nurul Yakin, Korong Ringan-ringan Pakandangan Padang Pariaman, jam 11.00 WIB, tanggal 22 Juli 2014. 
ditetapkan sebagai tanggal 30 Sya'ban (istikmâl) $^{11}$.

Penetapan tanggal 29 Sya'ban menurut perhitungan taqwim Khamsiyah dilakukan oleh orang yang ahli dibidang tersebut, yakni dengan menggunakan metode hisab 'Urfi yang berdasarkan kepada huruf tahun dan huruf bulan.

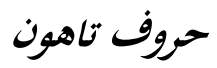

\begin{tabular}{lcc}
\hline \multicolumn{1}{c}{ Ket } & Huruf & Angka \\
\hline $\begin{array}{l}\text { awal } \\
\text { perhitungan } \\
\text { Khamisiah }\end{array}$ & । & 1 \\
\hline & 5 & 3 \\
\hline & $j$ & 7 \\
\hline & 2 & 4 \\
\hline & 2 & 6 \\
\hline &, & 4
\end{tabular}

Tabel 1.(sumber wawancara langsung dengan Tuangku Ali Imaran Ulama Syatariah, tempat Pesantren Nurul Yakin Giring-giring Pakandangan Padang Pariaman tanggal 22 Juli 2014).

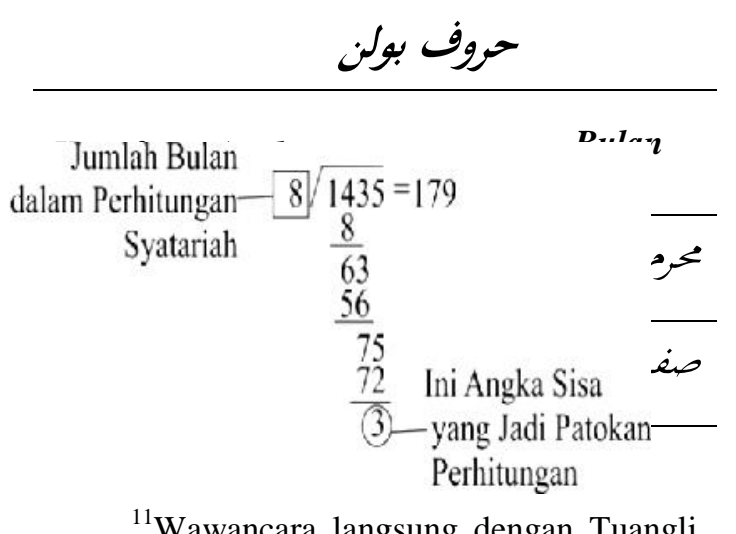
Ali Imaran, bertempat di Pesantren Nurul Yakin, Korong Ringan-ringan Pakandangan Padang Pariaman, jam 11.00 WIB, tanggal 02 Mei 2014

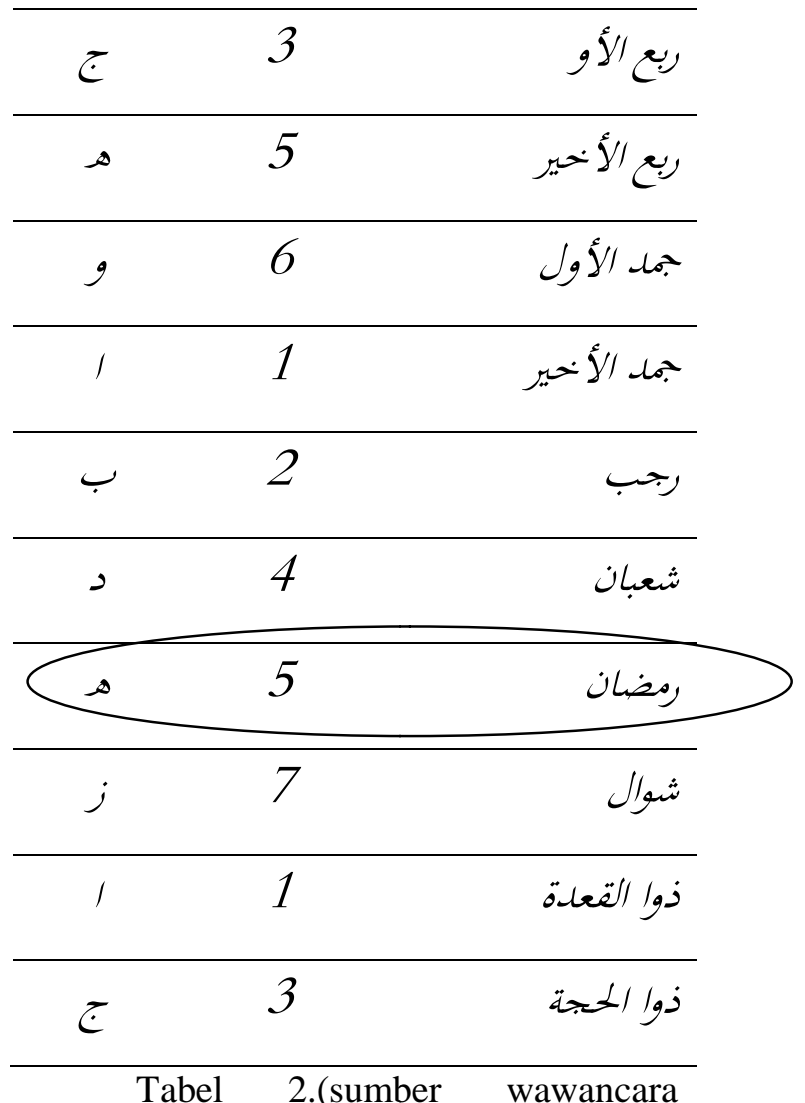

langsung dengan Tuangku Ali Imaran Ulama Syatariah, tempat Pesantren Nurul Yakin Giring-giring Pakandangan Padang Pariaman tanggal 22 Juli 2014).

Cara mencari huruf tahun : dibagi tahun itu dengan 9 kemudian berapa sisanya di hitung dari huruf $\mathrm{Ha}$ (ه) karena huruf itu adalah huruf awal tahun Khamisiyah. Contohnya :

\section{Rumusnya : \\ Langkah 1 :}




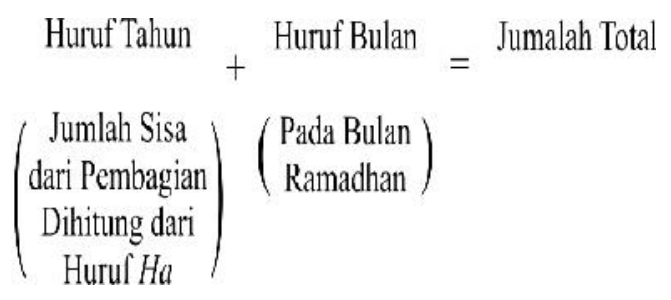

Langkah 2 :

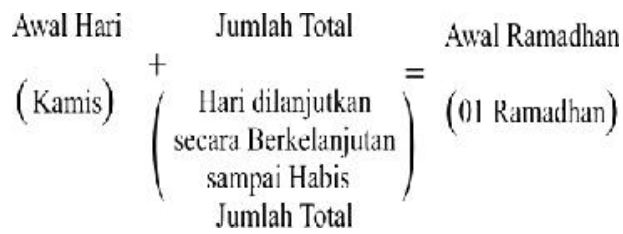

Contoh mencari hari/tanggal untuk melihat bulan pada tahun $1435 \mathrm{H}$ :

$$
\begin{aligned}
& \text { Jumlah Bulan } \\
& \text { dalam Perhitungan }-8 \sqrt{1435}=179 \\
& \text { Syatariah } \quad \frac{8}{63} \\
& \frac{56}{75} \\
& 72 \text { Ini Angka Sisa } \\
& \text { (3) - yang Jadi Patokan } \\
& \text { Perhitungan }
\end{aligned}
$$

dan ketika kita lihat pada kolom huruf tahun dan huruf bulan maka didapatkan hasilnya $7+5=12$

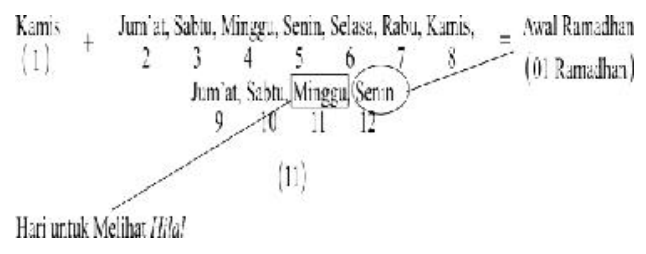

Hasilnya adalah : Minggu merupakan waktu untuk melihat bulan (hilal) dan Senin adalah awal Ramadhan.

Jadi, lebih 3 dari hasil pembagian di atas dihitung dari huruf $\mathrm{Ha}(\rightarrow)$ dan hasilnya berada di huruf $\mathrm{Za}$ ( ), yang kalau kita lihat pada kolom huruf tahun maka jumlah angkanya adalah 7. Selanjutnya kita jumlahkan dengan huruf bulan pada bulan ramadhan yang jumlah hurufnya adalah 5, setelah itu kita jumlahkan keduanya sehingga memperoleh hasil 12. Angkat 12 inilah yang menjadi acuan untuk menentukan tanggal 01 Ramadhan. Setelah itu dihitung mulai hari kamis sebagai awal hitungan sehingga ketika dilanjutkan maka 12 itu jatuh pada hari senin dan itu adalah tanggal 01 Ramadhan menurut perhitungan Takwim Khamisiyah Syatariah, dan 1 hari sebelumnya merupakan tanggal untuk melihat bulan (ru'yat al-hilal) ketika kelihatan maka puasa tapi ketika tidak kelihatan makan digenapkan menjadi 30 hari dan lusanya menjadi tanggal 01 Ramadhan.

Keputusan oleh tuangku Ali Imran sebagai ulama besar Tareka Syatariah, menjadi acuan bagi jama'ah paham Syattariyah untuk hadir di Ulakan guna melihat bulan tepat pada Jam 17.00 WIB di pantai Ulakan sepanjang $1 \mathrm{KM}$ atau di daerah Koto Tuo yang sudah menjadi tempat yang di sepakati untuk menyaksikan kehadiran hilal Ramadhan.

Demikianlah pengaruh tradisi melihat bulan terhadap sikap dan amaliyah ulama Syattariyah. Pengaruh ini cukup kuat di tingkat bawah. Di wilayah pedesaan dapat dilihat orangorang yang masih makan dan minum secara terbuka di warung siang hari pada tanggal 01 Ramadhan menurut penetapan Menteri Agama. Sebaliknya juga dapat dilihat orang-orang masih berpuasa pada tanggal 01 Syawal menurut penetapan Menteri Agama. Ini menunjukkan bahwa pengaruh tradisi melihat bulan di tengah masyarakat masih kuat. Walaupun saat ini teknologi informasi sudah menjangkau segenap aspek kehidupan masyarakat, namun informasi itu belum dapat merubah sikap dan amaliyah pengikut paham Syattariyah, sejalan dengan 
loyalitas mereka kepada ulama yang mengajarkan paham Syattariyah.

Ulama Syattariyah beserta peng-ikutnya hingga saat ini masih loyal terhadap tradisi melihat bulan. Sekalipun tradisi tersebut kelihatannya statis, namun sedikit banyaknya tetap mengalami dinamika sesuai dengan perkembangan yang terjadi di tengah mnasyarakat. Munculnya kelompok Arba'iyah menunjukkan adanya dinamika tersebut.

Bahkan di kalangan ulama Syattariyah yang mengikuti taqwim Khamsiyah sendiri ada yang membolehkan perbedaan secara pribadi dalam memulai dan mengakhiri ibadah puasa Ramadhan. Misalnya pada hari Senin sudah ada informasi bahwa hilal telah kelihatan, sedangkan rukyat hilal menurut jadwal taqwim akan dilaksanakan pada hari Selasa. Bagi yang sudah meyakini adanya hilal diperbolehkan berpuasa secara pribadi. Yang tidak boleh adalah merubah jadwal rukyat hilal dalam sistem perhitungan taqwim yang sudah ada. Ini disampaikan oleh Tuangku Ali Imran Hasan dari Pesantren Nurul Yaqin menegaskan bahwa ia berpegang kepada taqwim Khamsiyah dalam penentuan jadwal rukyat hilal untuk penetapan tanggal 01 Ramadhan dan 01 Syawal. Menurut Syekh Ali Imran Hasan, sikapnya yang demikian sesuai dengan fatwa gurunya ketika di Ampalu Tinggi, yaitu Haji Ibrahim ${ }^{12}$.

Jika dicermati secara detail beberapa kasus di atas, menunjukkan adanya dinamika dalam tradisi melihat bulan. Dinamika itu muncul sejalan dengan perkembangan yang terjadi di tengah masyarakat.

\footnotetext{
12 Wawancara langsung dengan Tuangku Ali Imran, Op.cit
}

\section{KESIMPULAN}

Berdasarkan beberapa uraian serta hasil penelitian yang penulis sajikan pada bab-bab sebelumnya, maka dapat diambil kesimpulan sebagai berikut :

. Pemahman ulama Syatariah terhadap hadis ru'yat al-hilal yakni adanya kesesuaian makna diantara kedua hadis tersebut dan juga pengkolaborasian dari keduanya sehingga tidak ada yang bertentangan, sejalan dengan pendapat yang dilontarkan oleh Tuangku Ali Imran bahwasannya "tidak mungkin sesuatu yang keluar dari orang yang dijamin masuk surga bisa bertentangan dan juga kalau seandainya hadis ini bertentangan tentu masa sahabat sudah terjadi hal yang demikian, kenyataannya tidak". Jadi, hadis yang kedua atau فان غمي عليكم فاقدرواله ini merupakan penjelasan lebih lanjut dari فان غمي yaitu seandainya tidak dapat dilihat menggunakan mata telanjang, maka hadis yang kedua menjadi penjelas dari hadis yang pertama yaitun diperkirakanlah sya'ban menjadi 30 hari. Penjelasan inilah yang dipegang oleh Tarekat Syatariah dan Ulama Syatariah sampai hari ini. Ketika berbicara tentang hisab dan alatalat modern mereka tidak menerima keputusan awal Ramadhan yang diambil dari proses tersebut, karena adanya bantuan dari alat-alat dan keilmuan-keilmuan yang baru. Akan tetapi untuk masalah ru'yat al-hilal bagi Tarekat Syatariah diperboleh-kan menggunakan alat-alat modern untuk melihat al-hilal, meskipun demikian hasil akhir tetap ditentukan dengan mata telanjang, seandainya dengan menggunakan alat-alat modern sudah 
terlihat dan ketika dilihat dengan mata telanjang belum terlihat, maka diputuskan al-hilal tidak kelihatan dan sya'ban digenapkan menjadi 30 hari. Bahkan hisab adalah hal yang mereka tolak secara terang-terangan karena tidak pernah dilakukan oleh Nabi saw dan para sabahatnya, dasar pemikiran mereka hanya satu sebagaimana yang disampaikan oleh Tuangku Ali Imran saat wawancara langsung di Ponpes Nurul Yakin Jorong Giring-giring Pakan-dangan Padang Pariaman : "Nabi saw adalah orang yang dijamin masuk surga dan para sahabat adalah orang yang sudah dijamin juga masuk surga, mereka saja orang yang punya ilmu dan keimanan jauh melampaui kita tidak pernah melakukannya, apalagi dibandingkan dengan kita orang yang belum tentu tempatnya di

\section{DAFTAR PUSTAKA}

Ahmad Izzuddin, Ilmu Falak Praktis (Metode Hisab-Rukyah Praktis Dan Solusi Permasalahannya), Semarang: Komala Grafika, 2006.

Almanak Hisab Ru'yat, Ditbinbapera Islam Depag,tt.

Al-Naisaburiy, Imam Abi al-Husaini Muslim ibn al-Hajjaj ibn Muslim al-Qurairiu, al-shahih al-Muslim, Beirut : Dar alFikri, tt.

Badan Hisab dan Rukyat Departemen Agama, Almanak $\mathrm{Hi}$ sab Rukyat, Jakarta: Proyek Pembinaan Badan Peradilan Agama Islam, 1981.

Direktorat Jenderal Bimbingan Masyarakat Islam Direktorat akhirat kelak". Dari penjelasan Tuangku Ali Imran ini jelaslah bahwa Tareka Syatariah memahami hadis ru'yat al-hilal dengan satu pemahaman yaitu melihat bulan secara langsung dengan mata telanjang.

2. Bentuk pengaplikasian dari hadis ru'yat al-hilal ini adalah dengan melihat al-hilal pada tanggal 29 sya'ban setelah mendapatkan izin atau pemberitahuan di jumat terakhir dari Ulama/Tuangku mereka ditempat yang sudah ditentukan sebelumnya yaitu Pantai Ulakan Padang Pariaman dan daerah Koto Tuo.

Hilal dinyatakan tampak apabila pada tanggal 29 sya'ban terlihat hilal dengan mata telanjang tanpa bantuan alat, dan disaksikan oleh 2 orang atau lebih.

Urusan Agama Islam dan Pembinaan Syari'ah, Pedoman Teknik Rukyat, Jakarta : tp, 2009.

Maizuddin, kajian islam, jurnal ilmu-ilmu keislaman, Padang: IAIN Imam Bonjol Padang, 2001.

Muhyiddin Khazin, Kamus Ilmu Falak, Jogjakarta:Buana Pustaka, 2005.

T.Jamaluddin. Pengertian dan Perbanding-an Mazhab tentang Hisab Ru'yat dan Matla', Padang : Makalah Munar Tarjih Muhammadiyah ke-26. 